\title{
Correction to: Window dressing: possibilities and limitations of incremental changes in solitary confinement
}

Dallas Augustine ${ }^{1 *}$, Melissa Barragan ${ }^{2}$, Kelsie Chesnut ${ }^{3}$, Natalie A. Pifer ${ }^{4}$, Keramet Reiter ${ }^{5}$ and Justin D. Strong ${ }^{5}$

Correction to: Health Justice 9, 21 (2021)

https://doi.org/10.1186/s40352-021-00145-7

Following the publication of the original article [1] the authors noticed that the published version of the manuscript has redacted and blinded citations.

The original article [1] has been updated.

\section{Author details}

${ }^{1}$ Department of Medicine, University of California, San Francisco, USA.

${ }^{2}$ Department of Sociology, California State Polytechnic University at Pomona, Pomona, USA. ${ }^{3}$ Vera Institute of Justice, Brooklyn, USA. ${ }^{4}$ Department of

Criminology and Criminal Justice, University of Rhode Island, Kingston, USA.

${ }^{5}$ Department of Criminology, Law \& Society, University of California, Irvine, USA.

Published online: 14 September 2021

\section{Reference}

1. Augustine, D., Barragan, M., Chesnut, K., et al. (2021). Window dressing: possibilities and limitations of incremental changes in solitary confinement. Health Justice, 9, 21 https://doi.org/10.1186/s40352-021-00145-7.

The original article can be found online at https://doi.org/10.1186/s40352 021-00145-7.

* Correspondence: dallas.augustine@ucsf.edu

${ }^{1}$ Department of Medicine, University of California, San Francisco, USA

Full list of author information is available at the end of the article

(c) The Author(s). 2021 Open Access This article is licensed under a Creative Commons Attribution 4.0 International License, which permits use, sharing, adaptation, distribution and reproduction in any medium or format, as long as you give appropriate credit to the original author(s) and the source, provide a link to the Creative Commons licence, and indicate if changes were made. The images or other third party material in this article are included in the article's Creative Commons licence, unless indicated otherwise in a credit line to the material. If material is not included in the article's Creative Commons licence and your intended use is not permitted by statutory regulation or exceeds the permitted use, you will need to obtain permission directly from the copyright holder. To view a copy of this licence, visit http://creativecommons.org/licenses/by/4.0/ The Creative Commons Public Domain Dedication waiver (http://creativecommons.org/publicdomain/zero/1.0/) applies to the data made available in this article, unless otherwise stated in a credit line to the data. 